\title{
Knowledge and Attitude of Intensive Care Nurses regarding the Prevention of Pressure Ulcer
}

\author{
Shahrokh Khojastehfar ${ }^{1},{ }^{*}$ Tahereh Najafi Ghezeljeh ${ }^{2}$, Shima Haghani $^{3}$
}

\begin{abstract}
Background \& Aim: Pressure ulcers are one of the indicators of the quality of nursing and health care. Nurses, as one of the main members of the health team, play an important role in the prevention of pressure ulcer in health care centers. Therefore, this study aimed to determine the knowledge, attitude, and practice of nurses in preventing pressure ulcer.

Materials \& Methods: This descriptive cross-sectional study was conducted in 2018. Through complete enumeration, all the employed intensive care unit nurses in the educational centers of Iran University of Medical Sciences were studied. Out of the 328 questionnaires, 308 questionnaires were completed by the participants. For data collection, Pieper Pressure Ulcer Knowledge Test (PPUKT) and Beeckman et al's attitude toward pressure ulcer questionnaire were used. Data were analyzed by SPSS software version 16, using independent t-test, Chisquare, Fisher's exact, and one-way ANOVA.

Results: According to the results, the mean score of knowledge and attitude of nurses regarding the prevention of pressure ulcer were $63.10 \pm 47.31,39.39 \pm 10.22$, respectively. The knowledge and attitude of the majority of nurses, regarding the prevention of pressure ulcer was at an undesirable level. Different groups of gender, background of continuous education, work experience, and experience in ICU had a significant difference in knowledge score. There were significant differences between different groups of gender, working hours per week, work experience, and work experience in ICU in terms of attitude score.

Conclusion: Considering the undesirable level of knowledge and attitude of nurses about the standards of prevention of pressure ulcers and the importance of improving the safety of patients admitted to the intensive care unit, it is suggested to develop appropriate educational planning to improve the knowledge and attitude of health care providers, especially nurses, in the area of prevention of pressure ulcer.
\end{abstract}

Keywords: Attitude, Bed sore, Knowledge, Nurse, Pressure ulcer, Prevention, Intensive care unit

\section{Conflict of Interest: No}

How to Cite: Khojastehfar SH, Najafi Ghezeljeh T, Haghani SH. Knowledge and Attitude of Intensive Care Nurses regarding the Prevention of Pressure Ulcer. Iran Journal of Nursing. 2019; 31(116):5-17.

Received: 6 Nov 2018

Accepted: 4 Feb 2019

1. MS. in Critical Care Nursing, Students Research Committee, School of Nursing and Midwifery, Iran University of Medical Sciences, Tehran, Iran.

${ }^{2}$. Associate Professor, Nursing Care Research Center, Iran University of Medical Sciences, Tehran, Iran; School of Nursing and Midwifery, Iran University of Medical Sciences, Tehran, Iran. (*Corresponding author) Tel: +982143651714 Email: najafi.t@iums.ac.ir

3. MS. in Biostatistics, Nursing Care Research Center, Iran University of Medical Sciences, Tehran, Iran. 


\title{
دانش و نكرش برستاران مر اقبتهاى ويزه در مورد ييشكيرى از زخم فشارى
}

\author{
شاهرخ خجسته فر '، :طاهره نجفى قزلجه '، شيما حقانى؟
}

جكيده

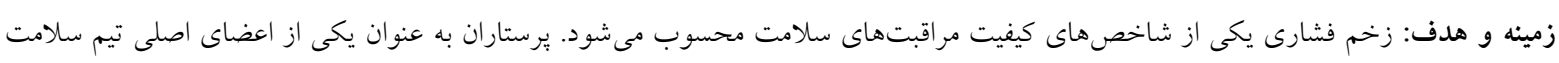

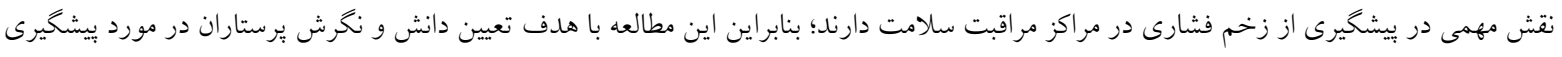
از زخمم فشارى انجام شده است.

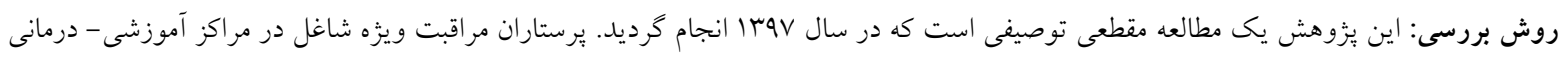

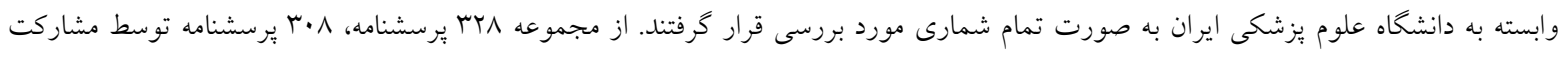

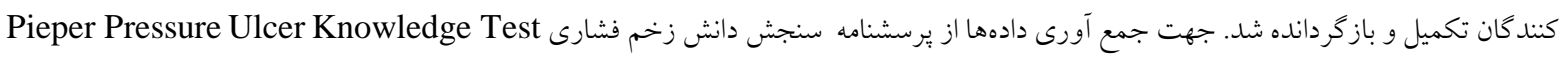

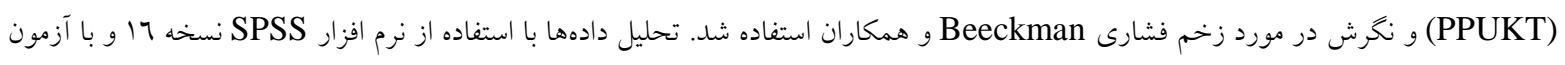

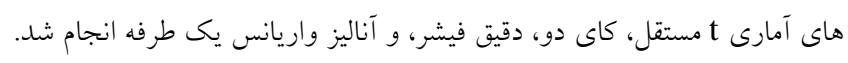

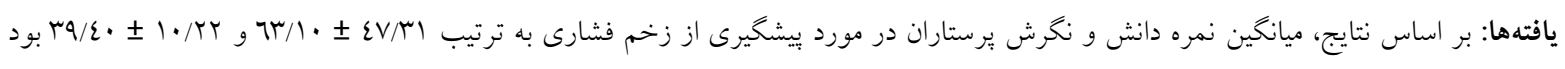

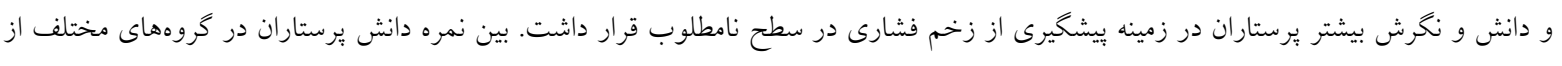

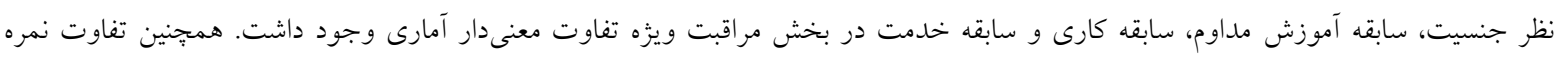

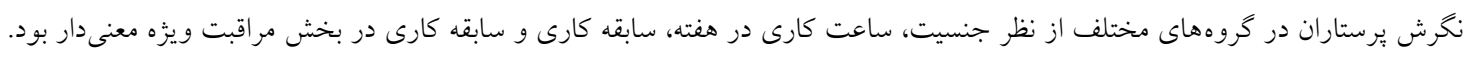

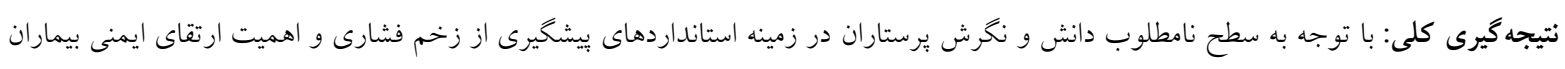

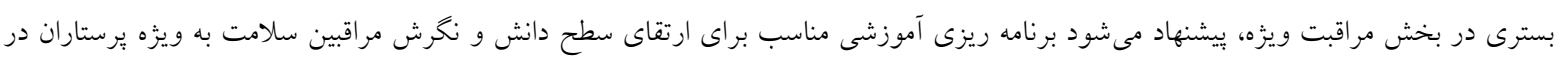

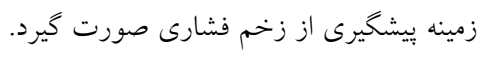

كليد وازمها: زخم فشارى، زخم بستر، نخرش، دانش، برستار، بيشخيرى، بخش مراقبت ويزه

تعارض منافع: ندارد

تاريخ دريافت: 9V/N/10

تاريخ يذيرش: TV/11/10

'. كار شناس ار شد ير ستارى مراقبت ويزه، كميته تحقيقات دانشجويى، دانشكده ير ستارى و مامايى، دانشًاه علوم يز شكى و خدمات بهدا شتى درمانى ايران، تهران، ايران.

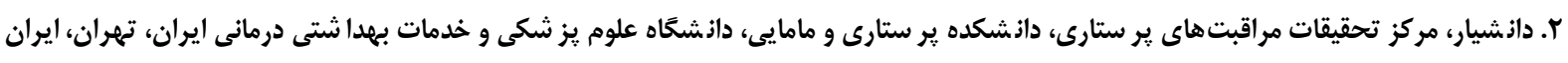
Email:najafi.t@iums.ac.ir

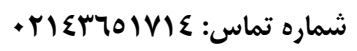

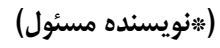
". كارشناسى ارشد آمار زيستى، مركز تحقيقات مراقبتهاى يرستارى، دانشكاه علوم يزشكى و خدمات بهداشتى درمانى ايران، تهران، ايران. 
در يِيشيرى و وِاسخكويى در مقابل بروز زخم فشارى

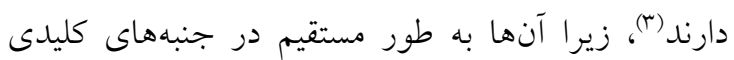

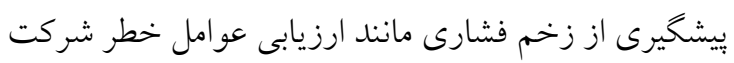

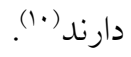
در ارائه مراقبت بِرستارى، برخوردارى از دانش بِايه و تجارب بالينى جهت ارتقاء كيفيت و ايمنى لازم است.

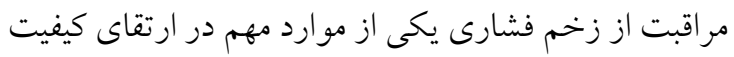

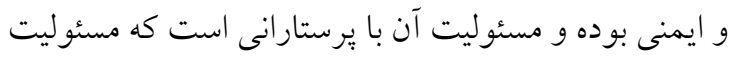

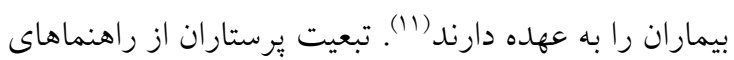

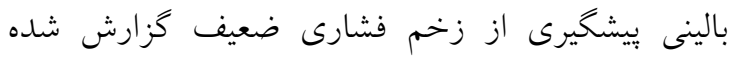

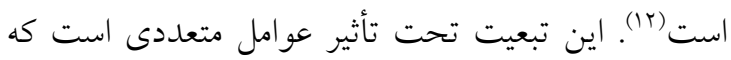
يكى از اين موانع مى تواند كمبود دانش درمورد اهميت اين

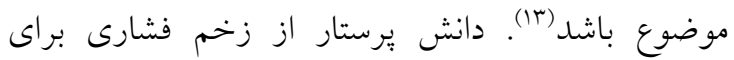

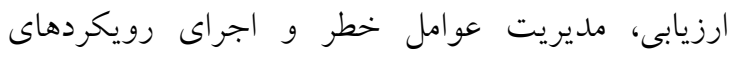

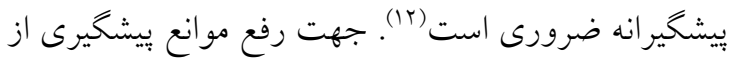
زخم فشارى در ICU و ساير بخشهاى بيمارستانى و

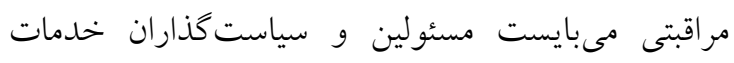

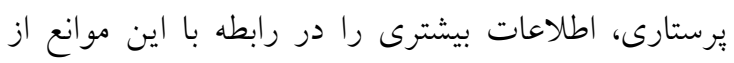

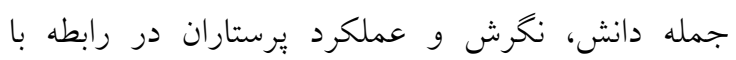

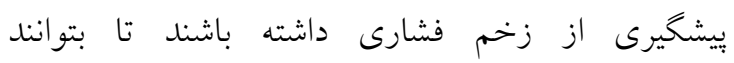

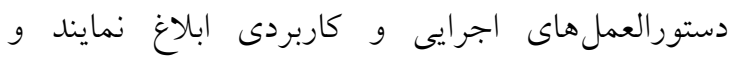

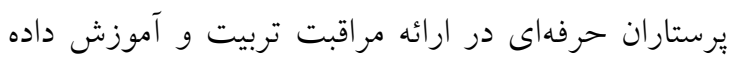
شوند. مديران يرستارى نيز مىبايست شرايط و كيفيت

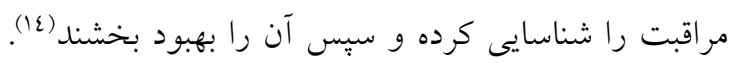

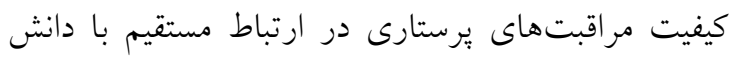

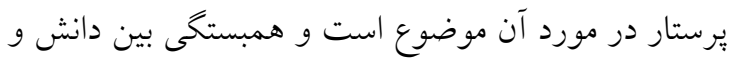

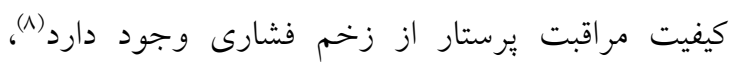

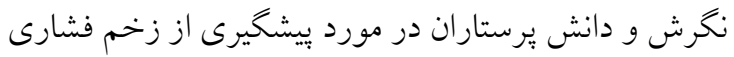

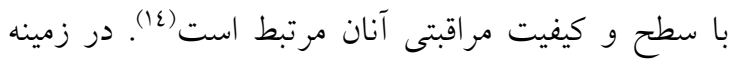
دانش، نخرش و رفتار يِيشيرى از زخم فشارى در

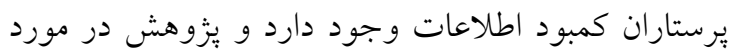
دانش و نخرش يرستاران در يبشخيرى از زخم فشارى

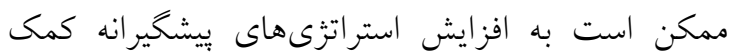
نمايل (10).

\section{مقدمه}

زخمهاى فشارى از مشكلات شايع و ناتوان كننده

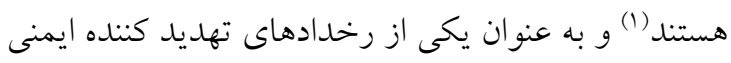
بيمار به شمار مى آيند (r). هر سال O, T, ميليون نفر در ايالات متحده به زخم فشارى مبتلا مىشوند كه از اين تعداد

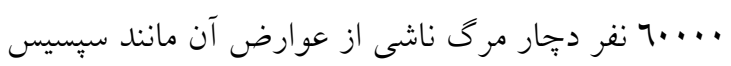

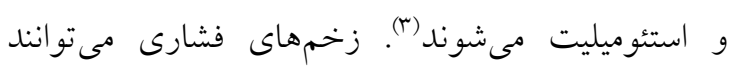
بيامدهاى نامطلوبى را براى بيمار، خانواده و مراقبين سازمانهاى بهداشتى رقم بزنند، هزينهاى درمانى زيادى را براى خانواده و مراكز درمانى به بار آورند و موجب بـانب

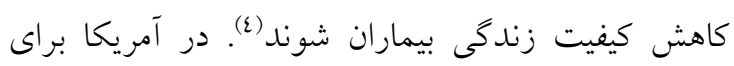
مديريت اين گونه زخمها 1,0,0 ميليارد دلار در سال هزينه مىشود كه .... 1 ا دلار از آن جهت درمان افرادى است كه زخم، تمام ضخامت يوست را دركير كرده است (r). با وجود يِيشرفتهاى علم و فن آورى هنوز زخمهاى Intensive Care ) فشارى در بخشهاى مراقبت ويزه يك مشكل جدى محسوب مى (Units /ICU بيماران بسترى در ICU به دليل وجود اقدامات تهاجمى مراقبتى و خطوط عروقى مركزى و تهويه مكانيكى بيشتر در معرض خطرات ناشى از بسترى همجهون زخم فشارى هستند (0). در ICU، بيشخيرى از وقوع حوادث به تيم مراقبت از بيماران و افراد آن تيم واخذار شده است آنها نه تنها مىبايست به فرآيند بيمارى اوليه بيماران توجه كنند

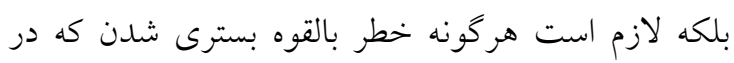
نهايت منجر به عوارض جانبى نيز مىشود را نيز مد نظر

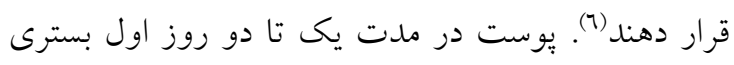

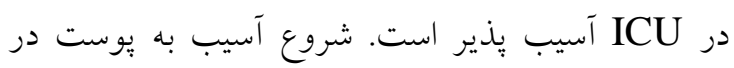
بيمار ان با وضيعت بحرانى در طى اين مدت رخ مىدهد (v). با توجه به اين كه بيماران بسترى در ICU بـه دليـل

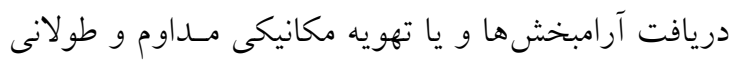
مدت در بستر محدود و بىحركت مسىشـوند خطـر آسيب يوستى در اين بيماران افزايش مى يابد (A). زخمهاى فشارى يكى از شاخص هاى بسيار مهم و حياتى

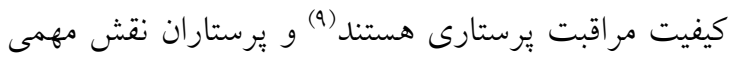


همه يرستاران وارد مطالعه شدند. از اين تعداد ^•r نقر

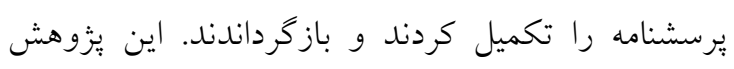
داراى ز (IR.IUMS.REC/1396.9511449002) دانشخاه علوم يزشكى ايران مىباشد.

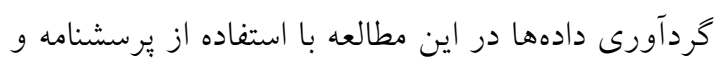

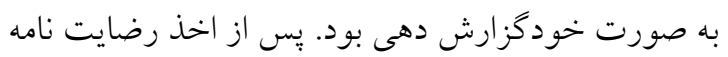

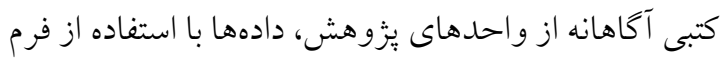

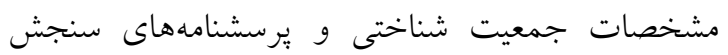
دانش زخم فشارى Pieper Pressure Ulcer Knowledge Test (PPUKT) زخم فشارى Attitude toward Pressure Ulcer جمع آورى شد بدين منظور خرسشنامهها (APuP) tool

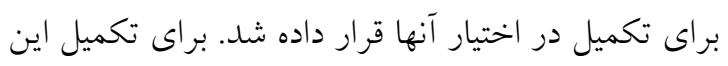

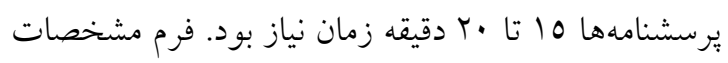

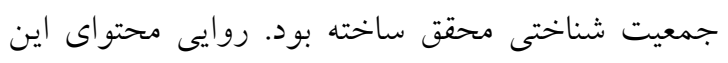

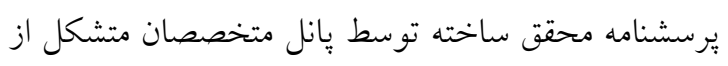

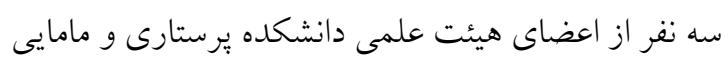
دانشخاه علوم يزشكى ايران بررسى و تأييد شد.

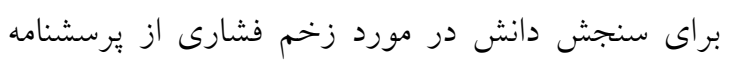
PPUKT بيشكيرى از زخم فشارى آمريكاى شمالى طراحى شده

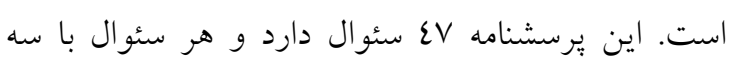

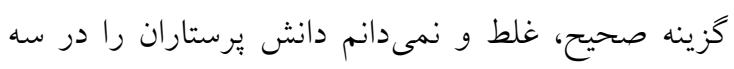

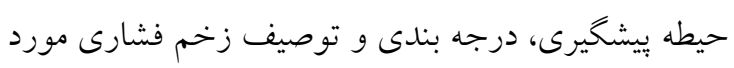

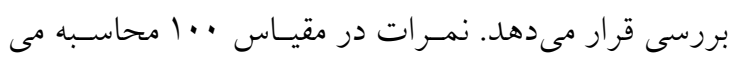

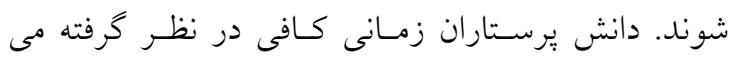

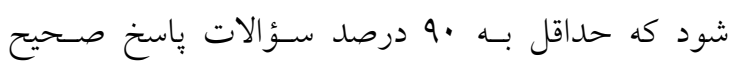

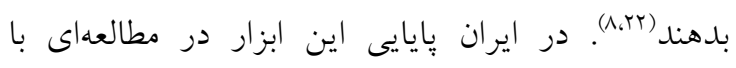

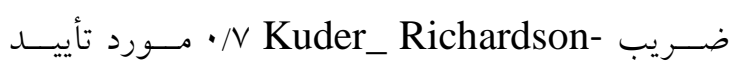
قـــرار كرفــت (1). در مطالعه حاضر ثبات درونى برسشنامه دانش با ضريب كودريجاردسون الب به ميزان 9V/. تأييد
در بررسى متون، دانش در مورد زخم فشارى در برخى

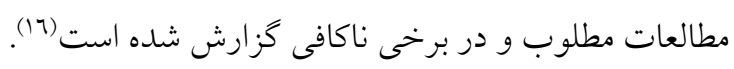

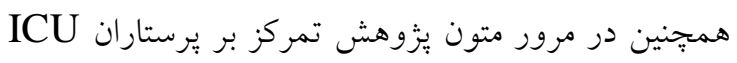

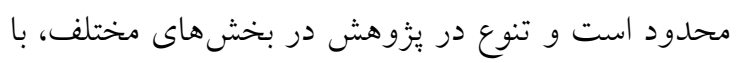

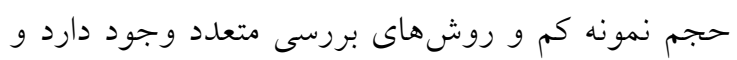

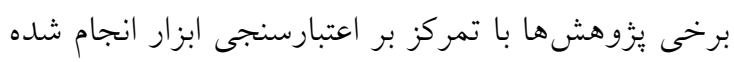

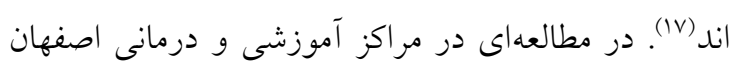

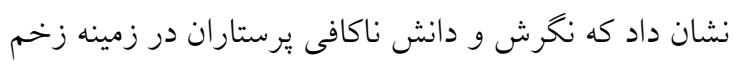

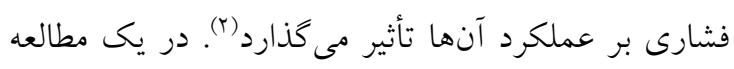

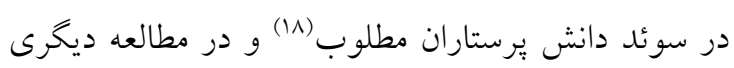

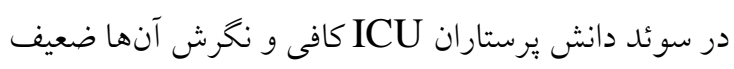

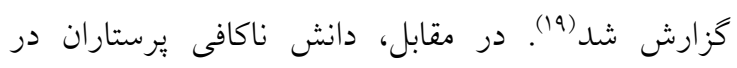

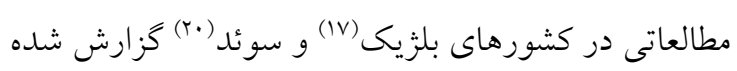

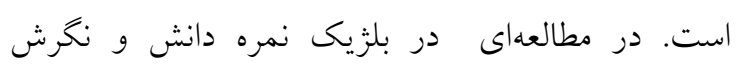

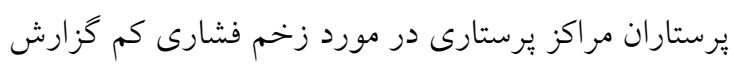

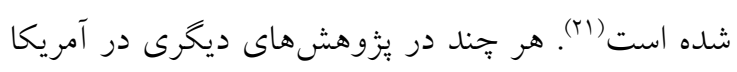

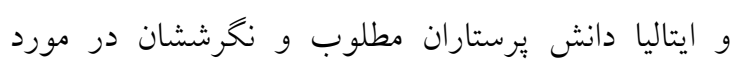

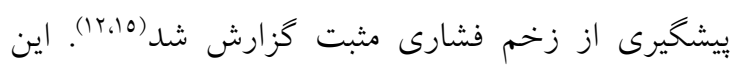

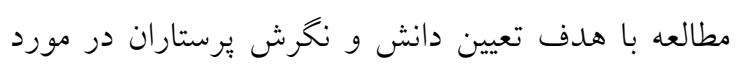

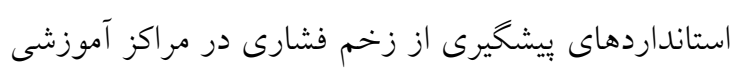

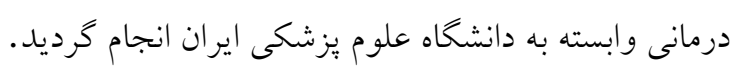

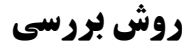

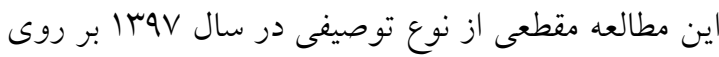
يرستاران شاغل در ICU مراكز آموزشى - درمانى دانشعاه

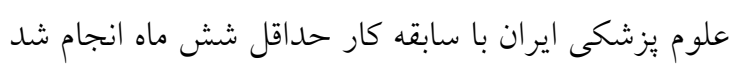

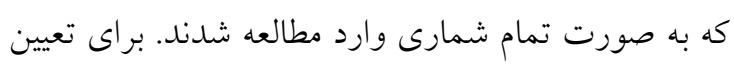

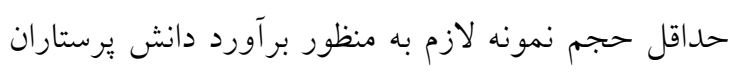
ICU

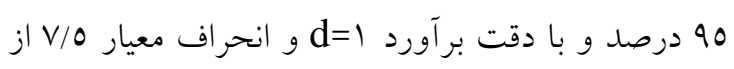

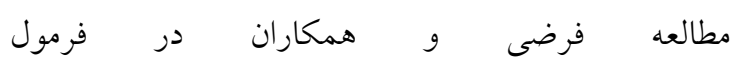
$n=\frac{z_{1-\alpha / 2}^{2} s^{2}}{d^{2}}=\frac{1.96^{2} \times 7.5^{2}}{1^{2}}=216$ حداقل حجم نمونه لازم آبا نقر بر آورد گرديد. از آنجايى

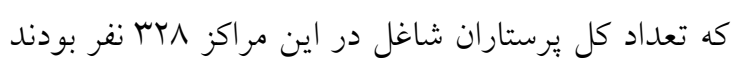


كرونباخ كع/N/ · براى نمونهاى مورد مطالعه بدست آمد و ثبات درونى ابزار تأييد شد.

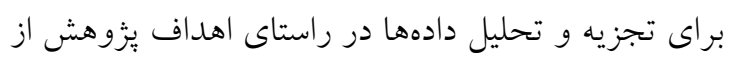
آمار توصيفى (فراوانى و درصد فراوانى براى متغيرهاى كيفى يززوهش و كمينه و بيشينه، ميانخين و انحراف معيار براى متغيرهاى كمى يزوهش) و آزمونهاى آمارى تى ئى

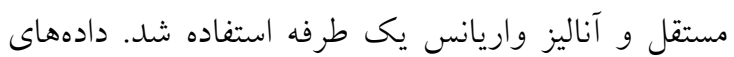
جمع آورى شده توسط نرم افزار كامييوترى SPSS نسخه r r تحليل شد و سطح معنى دارى كمتر از 0 • • در نظر كرفته شد.

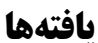

در مجموع ع9 درصد شركت كنند گان در يزوهش حاضر به بِرسشنامهها ياسخ كامل دادند. از اين تعداد، ع/rم درصد واحدهاى يززوهش زن با رده سنى •ع - الب بودند. بيشتر واحدهاى مورد يزوهش داراى مدرك كارشناسى برستارى بوده و بيشترين فراوانى در رابطه با سابقه كارى 9 -0 سال

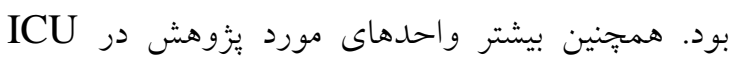

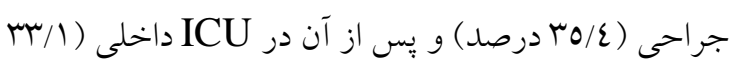
درصد) مشغول به كار بودند. همينطور بيش از نيمى از واحدهاى مورد يزّوهش دارى سابقه آموزشى در زمينه

$$
\text { زخم فشارى نبودند (جدول شماره (). }
$$
بر اساس نتايج، دانش همه يرستاران مورد يزّوهش در سطح نامطلوب (كسب كمتر از •9٪ نمره دانش) قرار داشت اما ميانخين نمره دانش كسب شده توسط برستاران

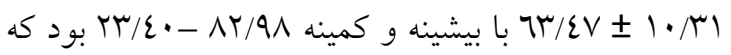
از ميانه نمره ابزار يعنى لم بالاتر است.
براى سنجش نخرش از يرسشنامه نخرش در مورد زخم فشارى با سا سئوال استفاده شد كه نخرش ذهنى افراد را نسبت به بيشخيرى از زخم فشارى اندازه كيرى مى كند. اين يرسشنامه ينج خرده مقياس دارد: صلاحيت فردى براى بيشخيرى از زخم فشارى، اولويتهاى بيشخيرى از زخم فشارى، تأثير زخم فشارى، مسئوليت بيشخيرى از زخم فشارى و اعتماد به اثربخشى بيشخيرى. نمره كل اين گويه ها با استفاده از مقياس ليكرت ينج حالتى (موافقم - كاملاً

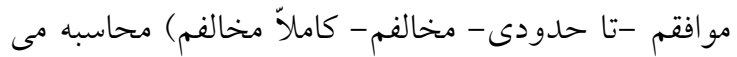
شود. نمرات كويههاى منفى در محاسبه نمره كل معكوس محاسبه مى گردند. بديهى است امتيازات بالاتر نخرش مطلوب و مثبت ترى را نشان مى دهند. براى توصيف نمونه ها، ميانخين نمره نخرش بيشتر يا مساوى V0 درصد رضايت بخش در نظر گرفته شد (ع). در مطالعهاى روايى محتواى آن

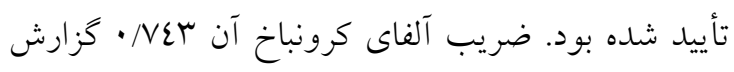
شده كه حاكى از مناسب بودن ثبات درونى ابزار مىباشد (ז'). در اين مطالعه براى استفاده از برسشنامه در

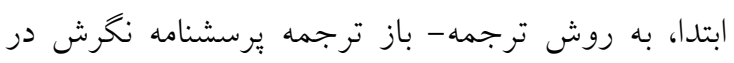

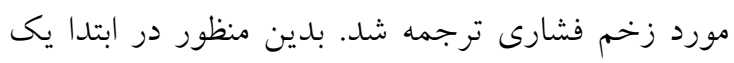

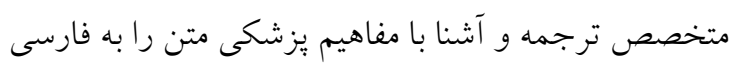
ترجمه كرد. سبِ متن ترجمه شده توسط يك مترجم (متخصص دو زبانه) ديخر از فارسى به انخليسى بركردانده

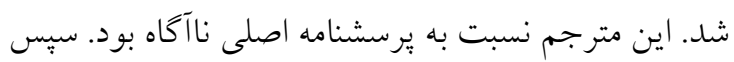
يزّوهشخران متنهاى ترجمه شده فارسى و انخليسى را با متن برسشنامه اصلى مقايسه كرده و در مورد مفاهيم و وازه ها به جمع بندى رسيدند. روايى محتواى اين يرسشنامه توسط يانل متخصصان متشكل از سه نفر از اعضاى هيئت علمى دانشكده يرستارى و مامايى دانشخاه علوم بزشكى ايران بررسى و تأييد شد. در مطالعه حاضر ضريب آلفاى

جدول شماره ا: مشخصات جمعيت شناختى واحدهاى مورد مطالعه و همبستىى آنها با دانش و نكَرش در زمينه ييشكيرى از زخم فشارى (N= (N) 


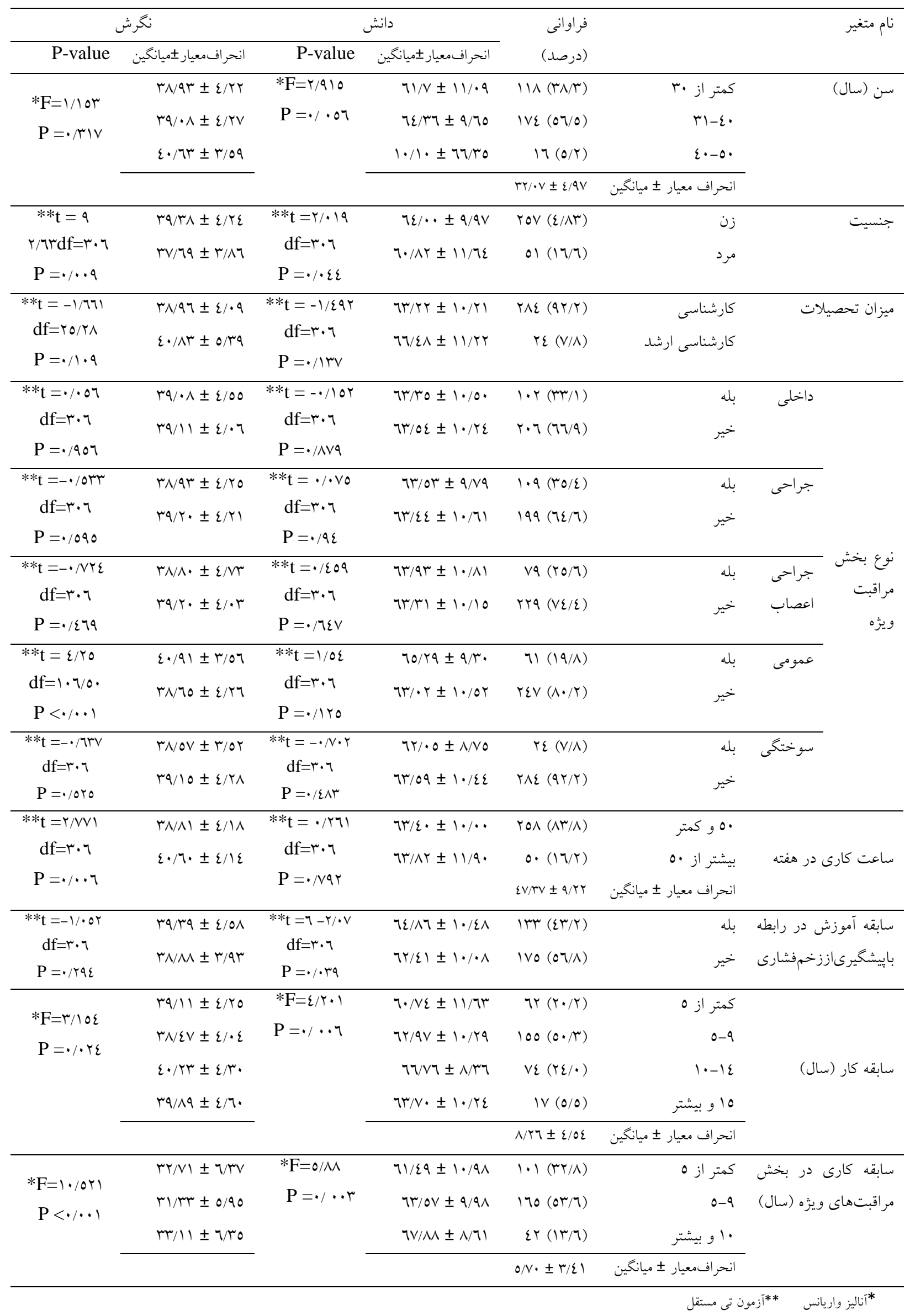


دادند. به ترتيب بيشترين درصد برستاران به گزينه مربوط

به تعريف زخم فشارى، عوامل خطر، تغذيه و جابه جا نمودن بيمار ياسخ صحيح دادند.
بر اساس جدول شماره rا، بيشترين تعداد برستاران به

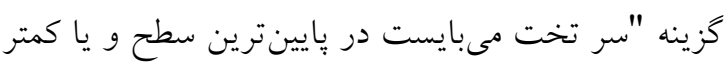

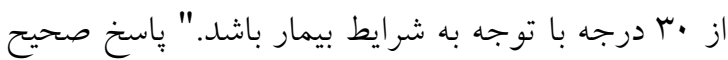

جدول شماره ؟: توزيع فراوانى سئوالات دانش برستاران شاغل در بخش مراقبتهاى ويزه در زمينه استانداردهاى ييشكَيرى از زخم فشارى

\begin{tabular}{|c|c|c|c|}
\hline نمى دانم & غلط & صحيح & 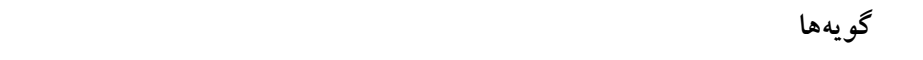 \\
\hline فراوانى (درصد) & فراوانى (درصد) & فراوانى (درصد) & \\
\hline $9(Y / 9)$ & $V(r / \Gamma)$ & $\operatorname{rar}(9 \varepsilon / \Lambda)$ & اريتم همر اه با قرمزى يوست به عنوان زخم فشارى درجه يك تعريف مىشود. \\
\hline $0(1 / 7)$ & $10(\varepsilon / 9)$ & $r \wedge \Lambda(9 \mu / 0)$ & تغذيه، تغييرات سطر براى آكَاهى. \\
\hline
\end{tabular}

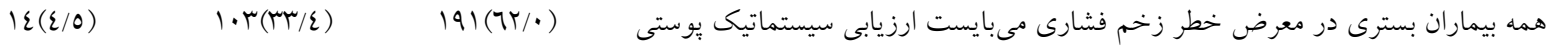

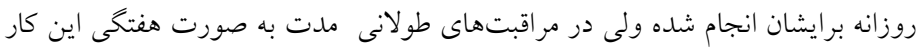

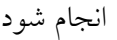

\begin{tabular}{|c|c|c|c|}
\hline$\varepsilon \cdot(1 \mu / \cdot)$ & $V 0(Y \varepsilon / \varepsilon)$ & $194(7 r / V)$ & آب گرم و صابون ممكن است يوست را خشك و به ايجاد زخم فشارى كمك نمايد. \\
\hline $10(\varepsilon / 9)$ & $r q(9 / \varepsilon)$ & $r\urcorner \varepsilon(\wedge O / V)$ & ماساز برجستخىهاى استخوانى مهم است. \\
\hline$\backslash \Lambda(0 / \Lambda)$ & $O r(I V / T)$ & $r M V(V Y / q)$ & مرگيرى اييدرم و درم و ضخامت نسبى يوست به عنوان زخم فشارى درجه مَ تعريف \\
\hline$V(T / \Gamma)$ & $10(\varepsilon / 9)$ & $r \wedge T(9 r / 9)$ & همه افراد در بيمارستان مىبايست مورد ارزيابى عوامل خطر ايجاد زخم فشارى قرار \\
\hline
\end{tabular}

\begin{tabular}{|c|c|c|c|}
\hline$\Lambda \Gamma(Y T / q)$ & $17(0 / r)$ & $r \cdot 9(7 V / 9)$ & 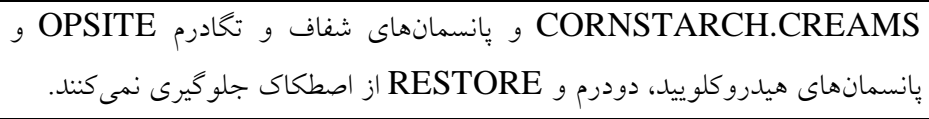 \\
\hline$r \varepsilon(V / \Lambda)$ & $r \cdot(T / 0)$ & rTE (^O/V) & 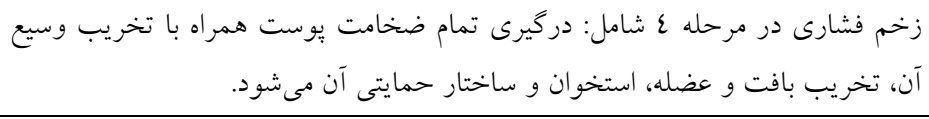 \\
\hline $\mathbb{1 r}(\varepsilon / r)$ & $\Lambda(Y / \tau)$ & $r \wedge \vee(q r / r)$ & مصرف غذاى مناسب داراى بروتئين و كالرى در طول بيمارى بايد حفظ شود. \\
\hline $0(1 / 7)$ & $17(0 / T)$ & $r \wedge \vee(q r / r)$ & افراد بسترى بايد هر ץ ساعت جابجا شوند. \\
\hline $1 \varepsilon(\varepsilon / 0)$ & $11(r / 7)$ & $r \wedge r(q) / q)$ & برنامه تغيير يوزيشن بيمار مىبايست نوشته شده و در كنار تخت بيمار قرار كيرد. \\
\hline $1 r(r / 9)$ & $\operatorname{IV}(0 / 0)$ & $\operatorname{rVq}(q \cdot / 7)$ & محافظ پياشنه باعث كاهش فشار بر روى پِشنه مىشود. \\
\hline$r I(T / \Lambda)$ & $1 \cdot(r / T)$ & $\operatorname{rVV}(\wedge q / 9)$ & 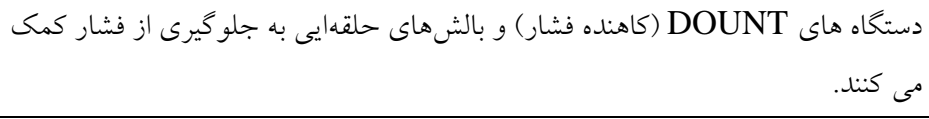 \\
\hline $09(19 / T)$ & Yr(V/I) & TrV $(V Y / V)$ & بيمار مىبايست در لترال يوزيشن •r درجه باشد. \\
\hline $00(1 V / 9)$ & $10 \mathrm{r}(\varepsilon 9 / \mathrm{V})$ & $1 \cdots(Y Y / O)$ & سرتخت مىبايست دريايينترين سطح ويا كمتراز ·r درجه با توجه به شرايط بيمار باشد. \\
\hline $1 \Lambda(0 / \Lambda)$ & $\operatorname{IV}(0 / 0)$ & $r V \Psi(\Lambda \Lambda / T)$ & فردى كه خودش را نمىتواند حركت دهد مىبايست هر دو ساعت در صندلى قرار گيرد. \\
\hline$r \wedge(9 / 1)$ & $1 \varepsilon(\varepsilon / 0)$ & $r า 7(\wedge T / \varepsilon)$ & 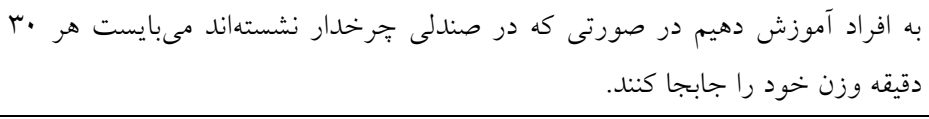 \\
\hline ro(N/1) & $11(r / 7)$ & $r V T(\Lambda \Lambda / \Gamma)$ & بر روى صندلى افرادى كه از صندلى استفاده مى كند بايد تشكجه نصب نمود. \\
\hline$r \wedge(9 / 1)$ & $\Lambda T(Y V / Q)$ & $19 \varepsilon(7 \pi / \cdot)$ & زخم درجه r تمام ضخامت يوست را دركير مى كند. \\
\hline$r V(\Lambda / \Lambda)$ & $r Y(V / I)$ & $\operatorname{roq}(\wedge \varepsilon / 1)$ & إيبدرم بايد تميز و خشك باقى بماند. \\
\hline$V Y(Y \Psi / \varepsilon)$ & $r\urcorner(\Lambda / \varepsilon)$ & $T I \cdot(T / / T)$ & بروز زخمهاى فشارى بسيار زياد است. \\
\hline
\end{tabular}




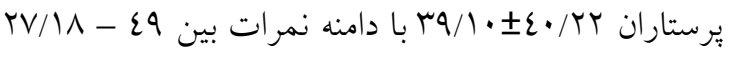

بود. از نظر ابعاد كمترين ميانكين مربوط به بعد اعتماد به

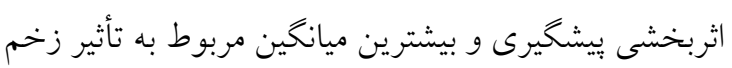

هم:جنين نخرش بيشتر برستاران مورد يُزوهش يعنى W/0 درصد در سطح نامطلوب و غير رضايتبخش بود (نمره كمتر از r ع) و تنها 0, اس درصد نخرش رضايت بخش و مطلوب داشتند. بر اساس جدول شماره ب ميانخين نمرات نخرش

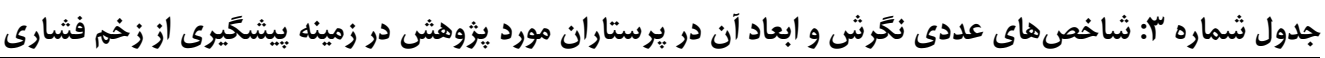

\begin{tabular}{|c|c|c|c|}
\hline بيشتر ين & كمترين & انحر اف معيار 土 ميانگين & 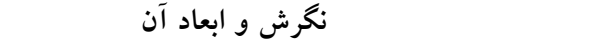 \\
\hline ir & 0 & $\Lambda / V V \pm 1 / \cdot r$ & صلاحيت فردى براى بيشخيرى از زخم فشارى (Y (Y-Y) \\
\hline ir & $\varepsilon$ & $\Lambda / N Y \pm 1 / \varepsilon$. & اولويتهاى بيشگيرى از زخم فشارى (Y-IY) \\
\hline ir & 0 & $9 / \cdot 0 \pm 1 / 20$ & تاثير زخم فشارى (Y-IT) \\
\hline$\wedge$ & r & $T / \mu \varepsilon \pm 1 / \mu r$ & مسئوليت ييشخيرى از زخم فشارى (Y-N) \\
\hline$\wedge$ & r & $T / r T \pm 1 / 1 \varepsilon$ & اعتماد به اثر بخشى بيشخيرى (Y-|Y) \\
\hline$\varepsilon 9$ & $r V / \Lambda \Lambda$ & $r q / 1 \cdot \pm \varepsilon / r r$ & نخحش (Yr-OY) \\
\hline
\end{tabular}

بر اساس جدول شماره ع بيشترين ميانخين نخرش مربوط به سئوال "بيشخيرى از زخم فشارى بايد در اولويت قرار كيرد" و كمترين ميانخين نخرش مربوط به سئوال "توجه

جدول شماره ع: توزيع فراوانى سوالات نترش يرستاران شاغل در بخش مراقبت هاي ويزه در زمينه بيشعَيرى از زخم فشارى

\begin{tabular}{|c|c|c|c|c|c|}
\hline \multirow[t]{2}{*}{ Mean \pm SD } & كاملاموافق نيستم & 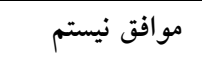 & 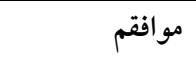 & 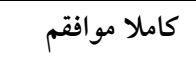 & \multirow[t]{2}{*}{ كويه ها } \\
\hline & فراوانى (درصد) & فراوانى (درصد) & فراوانى (درصد) & فر اوانى (درصد) & \\
\hline \multirow[t]{2}{*}{$r / r o \pm \cdot / \varepsilon \varepsilon$} & $\cdot(\cdot / \cdot)$ & $r(\cdot / 7)$ & $r T V(V T / V)$ & $V 9(T 0 / 7)$ & در مورد توانايىام براى ييشخيرى از زخم هاى فشارى \\
\hline & & & & & 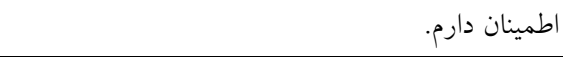 \\
\hline$r / 1 \varepsilon \pm \cdot / 00$ & $0(1 / 7)$ & $1 \varepsilon(\varepsilon / 7)$ & $Y T \cdot(V I / V)$ & $\neg(Y Y / I)$ & بر ایييشخيرى اززخممهاىفشارىخوبآموزش ديدهام. \\
\hline \multirow[t]{2}{*}{$r / T V \pm \cdot / V q$} & $Y I(T / \Lambda)$ & $110(\mathrm{rV} / 0)$ & $\mid \mu r(\Sigma \Psi / \cdot)$ & $r q(I T / V)$ & ييشخيرى از زخم فشارى خيلى مشكل است. ديكران \\
\hline & & & & & بهتر از من هستند. \\
\hline \multirow[t]{2}{*}{$1 / 9 \cdot \pm \cdot / 7 r$} & $\tau(Y / \cdot)$ & $r\urcorner(\Lambda / 7)$ & $r \cdot \cdot(77 / \varepsilon)$ & $79(Y Y / 9)$ & توجه خيلى زيادى صرف يشيخيرى از زخمهاى \\
\hline & & & & & فشارى مى شود. \\
\hline$r / 2 r \pm \cdot / 10$ & $\operatorname{l\wedge r}(7 \cdot / r)$ & $\Lambda)(Y \backslash / \Lambda)$ & $r Y(V / r)$ & $\operatorname{IV}(0 / 7)$ & ييشخيرى از زخم فشارى آن قدر هم مهم نيست. \\
\hline$r / 2 r \pm \cdot / v 1$ & $\tau(Y / \cdot)$ & $r I(\cdot / N)$ & $11 \cdot(\mathrm{rr} / \mathrm{\Lambda}$ & $17 r(0 \varepsilon / T$ & يششخيرى از زخم فشارى بايد در اولويت قرار گيرد. \\
\hline \multirow[t]{2}{*}{$\mu / \mu 1 / \cdot \cdot$} & $19 \cdot(7 r / 0)$ & $\left.\sum\right)(\mid r / 0)$ & $29(17 / 1)$ & $r \varepsilon(V / q)$ & زخم فشارى تقريبا هرگز براى بيمار ايجاد ناراحتى و \\
\hline & & & & & مشكل نمى كند. \\
\hline$r / M I \pm \cdot / 90$ & $\left.\sum\right\rceil(17 / 0)$ & $\varepsilon \varepsilon(10 / \Lambda)$ & $\operatorname{lrV}(\varepsilon q / \Gamma$ & $01(1 / / \Gamma)$ & تاثيرزخمهاىفشارىبر بيمارنبايدمورداغر اققرارگيرد. \\
\hline$\mu / \mu\urcorner \pm \cdot / \tau \varepsilon$ & $r(1 / \cdot)$ & $19(7 / \pi)$ & $\mid \varepsilon \wedge(\varepsilon \wedge / \vee$ & $1 r \varepsilon(\varepsilon \varepsilon / 1$ & تاثير مالى زخمهاى فشارى بر جامعه بالاست. \\
\hline$r / 97 \pm \cdot / 9 r$ & $99(\pi / T)$ & $\| \varepsilon(\Upsilon \wedge / \Gamma)$ & $09(19 / 1)$ & $r\urcorner(\Lambda / V)$ & اكربيمار ان مندجار زخمبسترشوند، منمسئول نيستم. \\
\hline$r / r q \pm \cdot / 71$ & $\varepsilon(1 / \Gamma)$ & $9(Y / 9)$ & $10 V(01 / \pi)$ & $1+7(\varepsilon \varepsilon / \varepsilon)$ & من وظيفه مهمى براى ييشخيرى از زخم فشارى دارم. \\
\hline \multirow[t]{2}{*}{$\mu / \mu \pm \pm \cdot / 00$} & $r(1 / \cdot)$ & $1 \cdot(\Gamma / \Gamma)$ & $r \cdot O(T V / \varepsilon)$ & $\Lambda\rceil(T \wedge / \Gamma)$ & زخمهاى فشارى در بيمارانى كه در معرض خطر بالا \\
\hline & & & & & 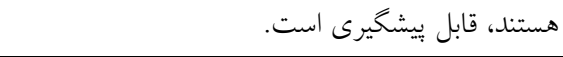 \\
\hline$r / 99 \pm \cdot / \wedge 7$ & $9 Y(Y 9 / 9)$ & $1 \varepsilon \varepsilon(\varepsilon\rceil / \Lambda)$ & $0 \cdot(1 T / T)$ & $r Y(V / I)$ & زخمهاى فشارى تقريبا و هرگز قابل بيشخيرى نيستند. \\
\hline
\end{tabular}


داشتند. نتايج آزمون شفه نشان داد كه نمره نخرش در افراد داراى سابقه بين 0-9 سال از افراد دار ایى سابقه كمتر از ينج

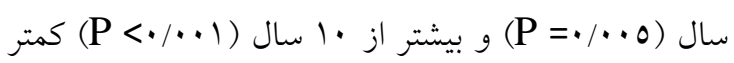

\section{بحث و نتيجه تيرى}

بر اساس نتايج اين يزوهش، دانش همه يرستاران مورد

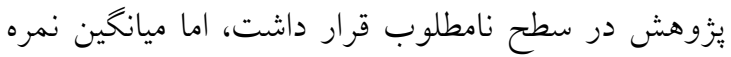
دانش يرستاران از ميانه نمره ابزار يعنى ل0 بالاتر بود كه اين مهم رامىتوان يكى از دلايل بالا بودن تراز ميانحين

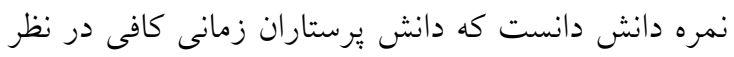

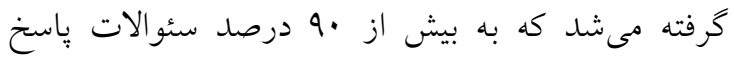

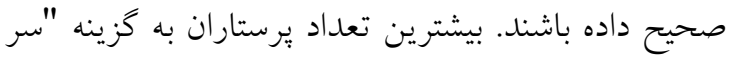

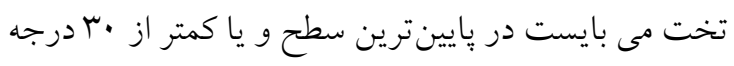

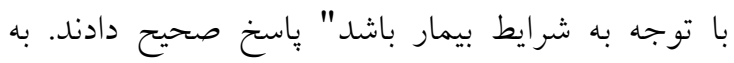

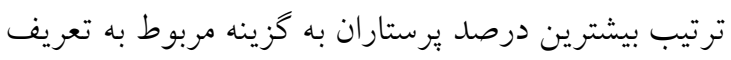

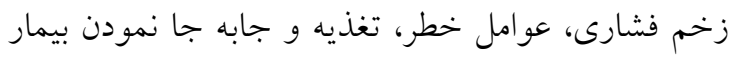

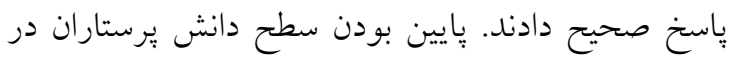

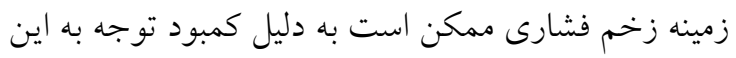

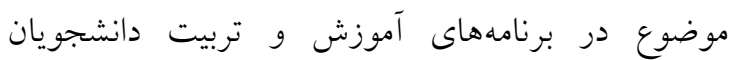
يرستارى باشد. دانش پايه اساسى براى كسب دانش بيشتر

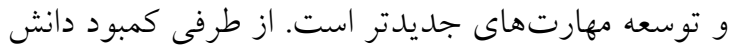
يرستاران در زمينه زخم فشارى مىتواند به برنامههاى

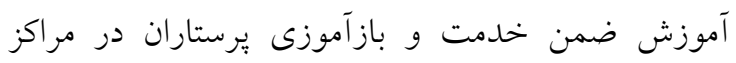

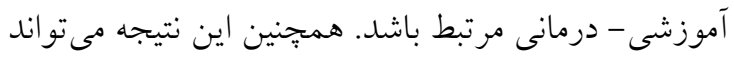
به مشغله كارى زياد يرستاران و امكان نداشتن شركت در برنامههاى آموزشى حضورى ارتباط داشته باشد، كما اين

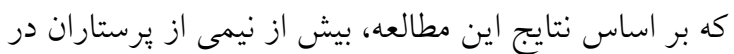

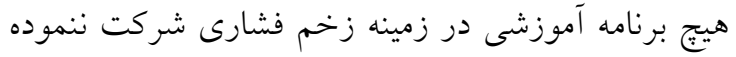
اند. ييشخيرى از زخم فشارى موردى مهم در مراقبت روزانه از بيماران در معرض خطر مىباشد كه ميزان دانش

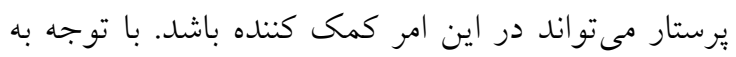

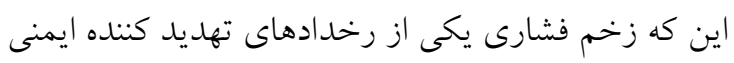

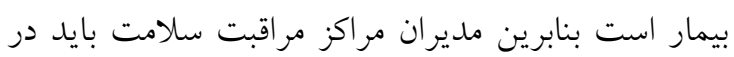

نتايج آزمون تى مستقل (جدول شماره () نشان داد كه كروههاى مختلف جنسيت از نظر نمره دانش تفاوت معنى

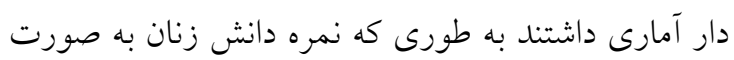
معنى دارى از مردان بيشتر بود. همجنين بين دانش برستاران

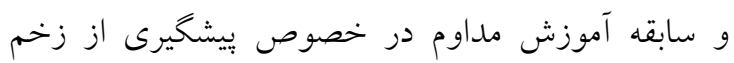

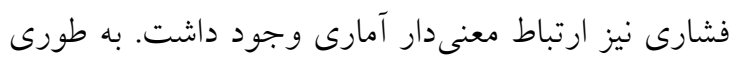

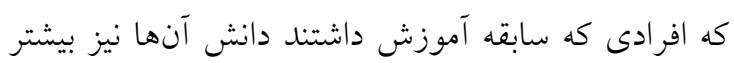

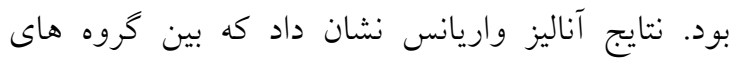
مختلف سابقه كارى يرستاران از نظر نمره دانش تفاوت

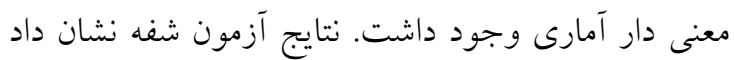

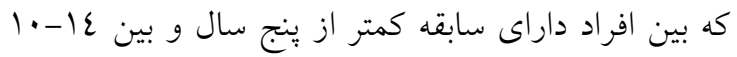

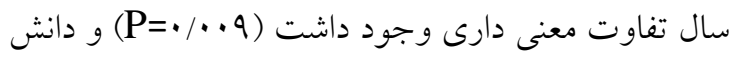
در افر اد داراى سابقه بين عا-- لـ سال بيشتر بود. نتايج آناليز واريانس نشان داد كه بين گرووهاى مختلف سابقه كارى ترائ يرستاران در ICU از نظر نمره دانش تفاوت معنىدار

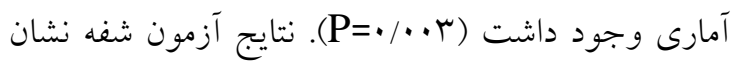

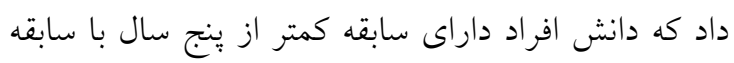

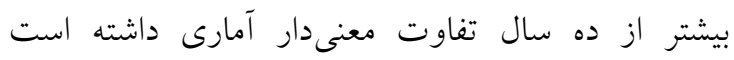

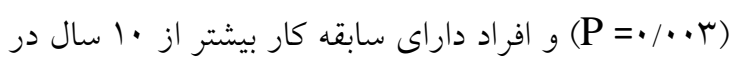
ICU نتايج آزمون تى مستقل (جدول شماره () نشان داد كه كروه دئن

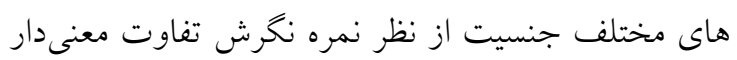

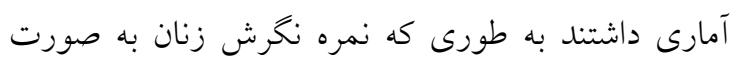
معنى

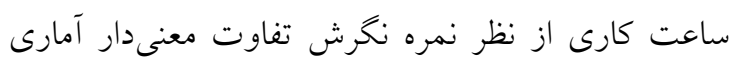

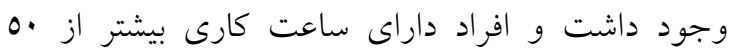
ساعت نخرش مثبت ترى نسبت به بيشخيرى از زخم فشارى

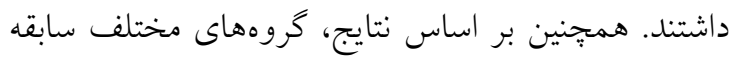
كارى از نظر نمره نخرش تفاوت معنى دارى داشتند. نتايج

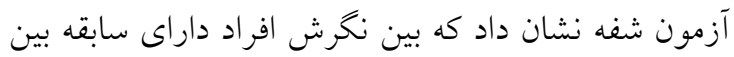
0-9 سال و عا--1ا سال تفاوت معنى دارى وجود داشت

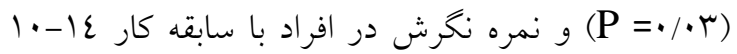
سال بيشتر بود. همجنين خروههاى مختلف سابقه كارى نـ

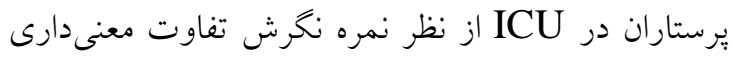


زنان در مقايسه با مردان مى تواند به بيشتر بودن حجم نمونه

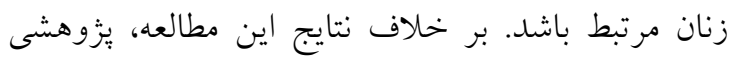

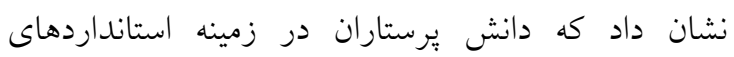
بيشخيرى از زخم فشارى با هيج يكى از متغيرهاى جمعيت دئن

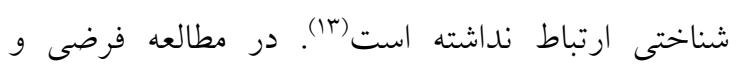
همكاران (r) در ايران نيز بين نمره دانش با جنس، سن، سابقه

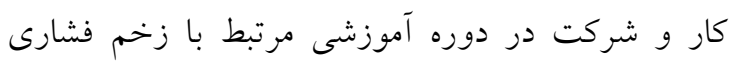
ارتباط معنىدارى يافت نشد. تفاوت در نتايج مطالعه مزبور با تيزوهش حاضر مىتواند به تفاوت در جمعيت مورد مطالعه مرتبط باشد. در يزوهش حاضر تمركز بر يرستاران

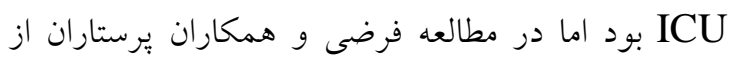
بخش هاى مختلف مورد بررسى قرار كرفتند.

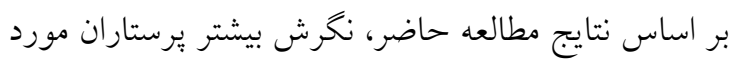

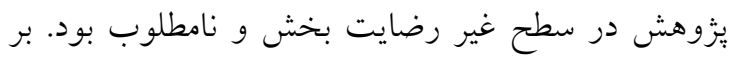

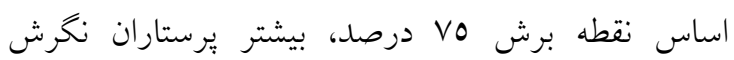

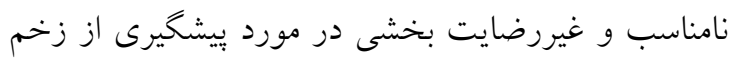

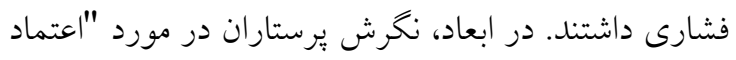

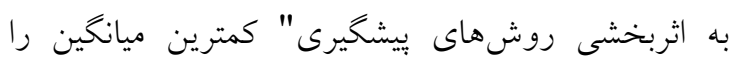

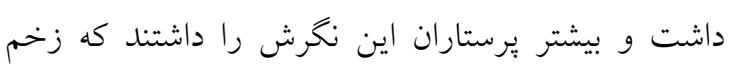

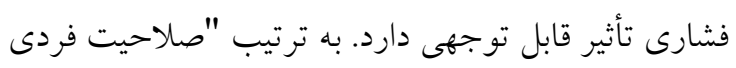

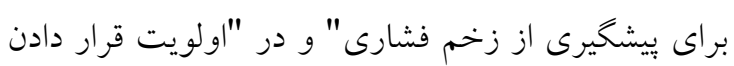
يميشيرى از زخم فشارى" را مهم مىدانستند. بيشترين

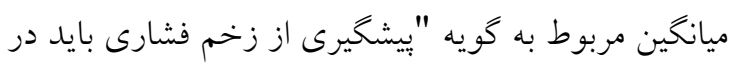

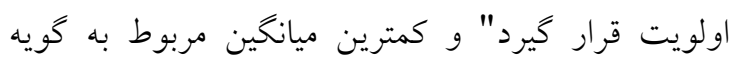

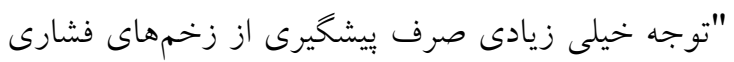

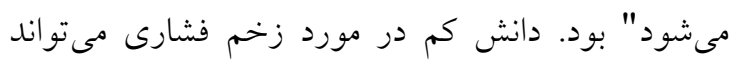

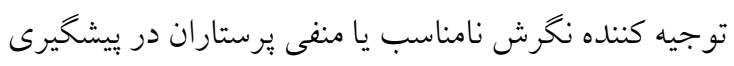

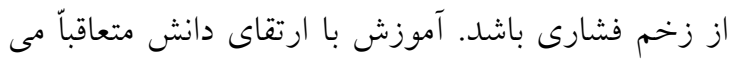

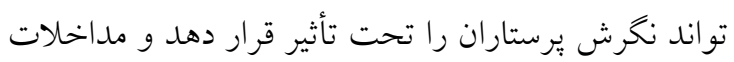

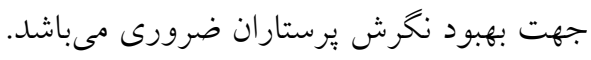

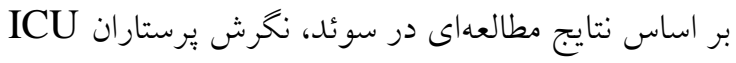

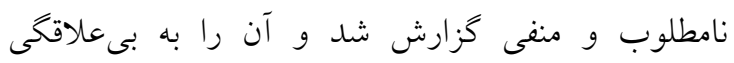

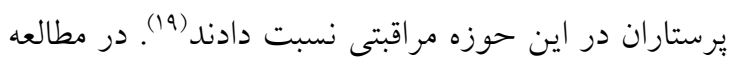

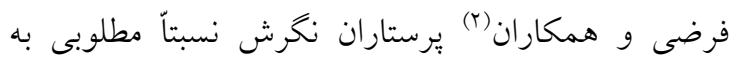

راستاى تو انمند سازى تيم سلامت به ويزّه برستاران برنامه

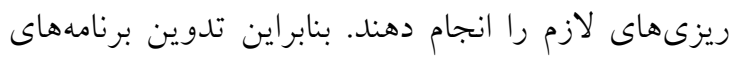

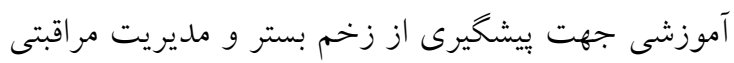

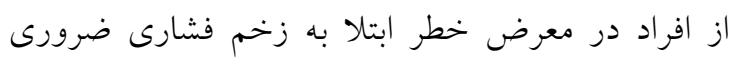

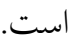
مطالعه حاضر با مطالعه ايرانمنش و همكاران(Tr) با هدف

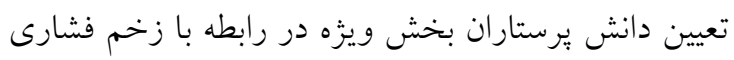

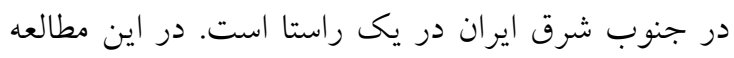

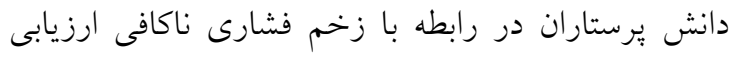

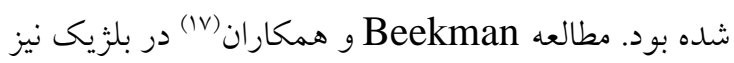

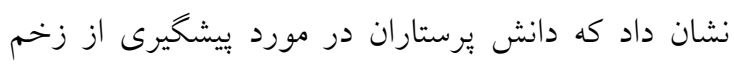

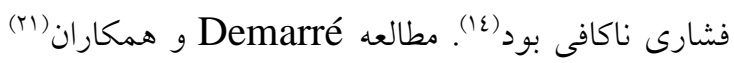

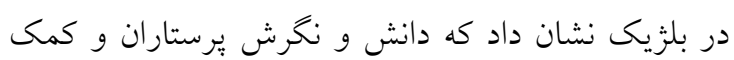

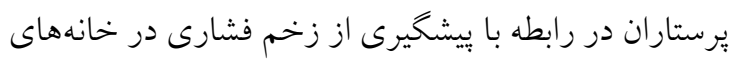

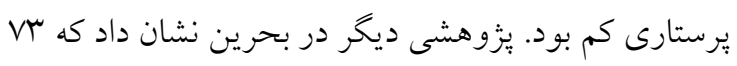

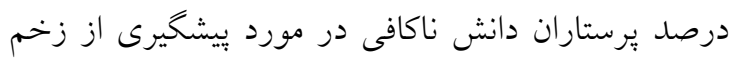

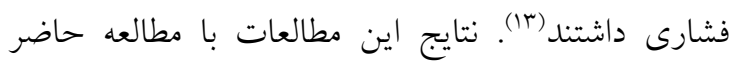

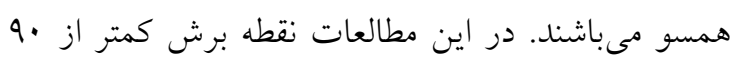

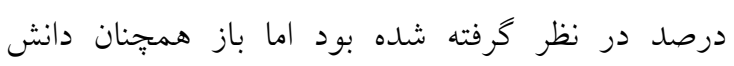
ير ستاران در زمينه زخم فشارى كم بود. مطالعهاى نشان داد

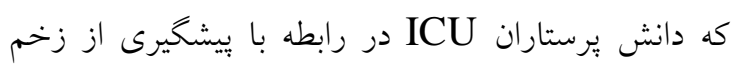

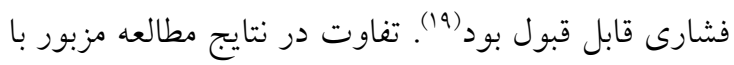

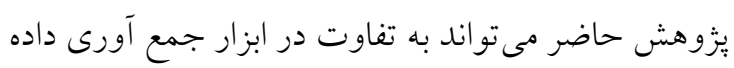

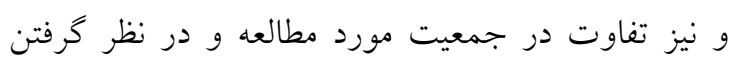
كاركنان برستارى غير حرفهاى مرتبط باشد.

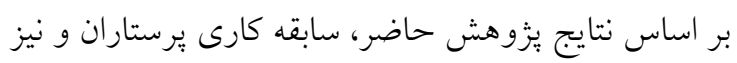

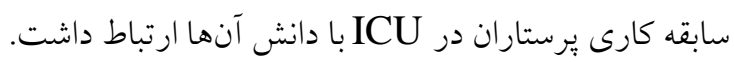
در مطالعهاى مشخص شد كه نمره دانش با سطح بـان تحصيلات، سابقه كار و آموزش رسمى در مورد بيشكيرى

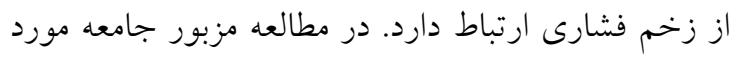

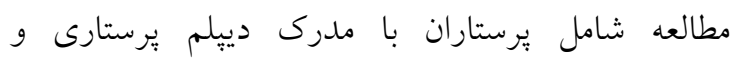

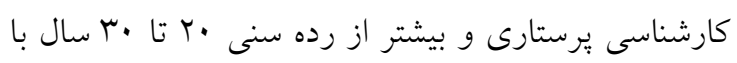

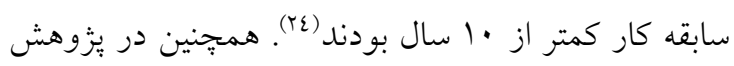

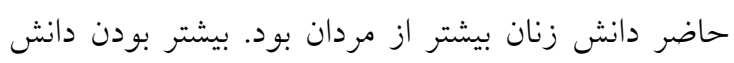


ترى در مراقبت از بيماران بسترى داشته باشند. همجنين در اين مطالعه نخرش مثبت تر برستاران با ساعات كارى بيشتر

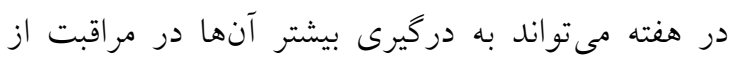

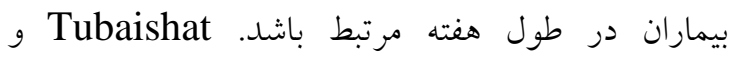

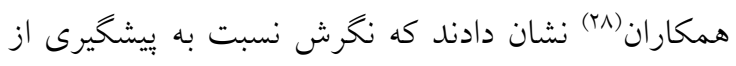
زخم فشارى با سابقه كارى ارتباط مثبت و معنىدارى

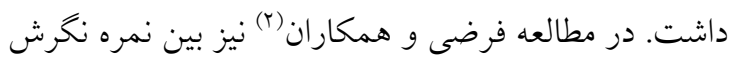

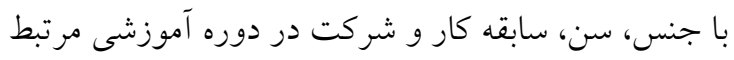
با زخم فشارى ارتباط معنىدارى يافت نشد. تفاوت در

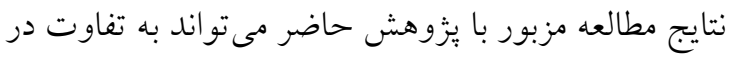
جمعيت مورد مطالعه مر تبط باشد. در ثيزوهش حاضر تمركز بر يرستاران ICU بود اما در مطالعه فرضى و همكاران يرستاران از بخش هاى مختلف مورد بررسى قرار كرفتند.

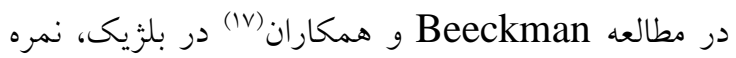

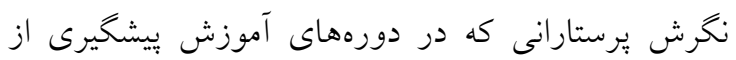

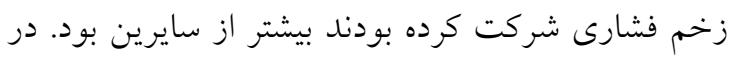

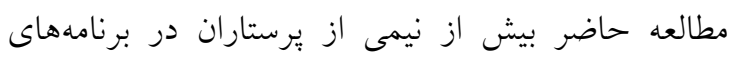

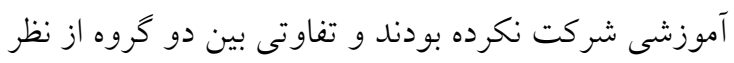

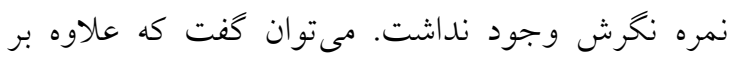

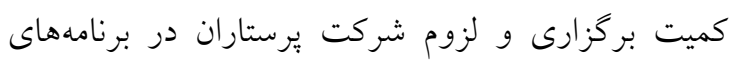

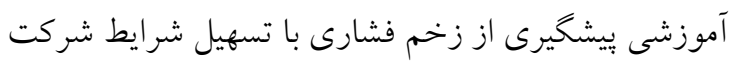

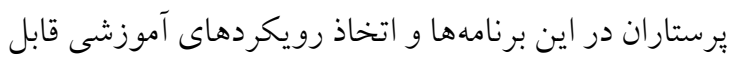
دسترس براى يرستاران بايد به كيفيت اين دورههاى آموزشى توجه ويزهاى شود.

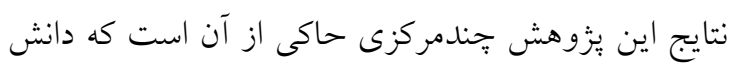

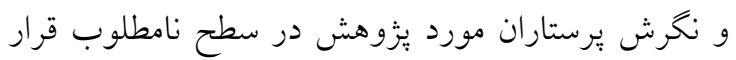

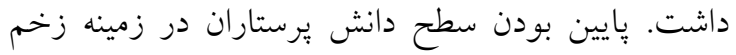
فشارى مىتواند به كمبود توجه به اين موضوع در برنامه

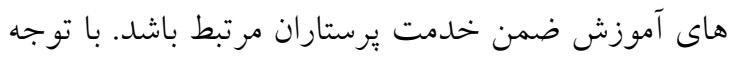
به اين كه زخم فشارى يكى از رخدادهاى تهايد كننده ايمنى بيمار است بنابرين مديران مر اكز مراقبت سلامت بايد در راستاى توانمند سازى تيم سلامت به ويزّه يرستاران

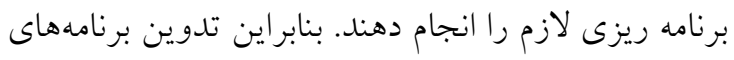

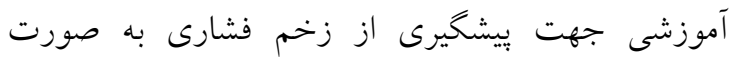

يشيخيرى از زخم فشارى داشته و توجه كمى به زخم

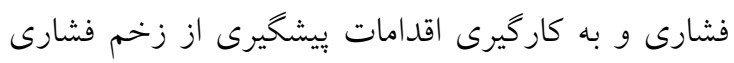

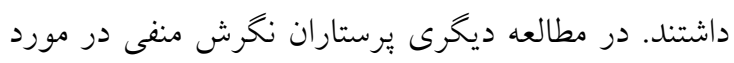

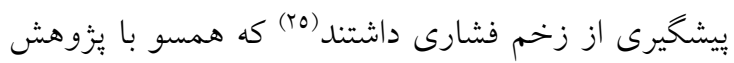

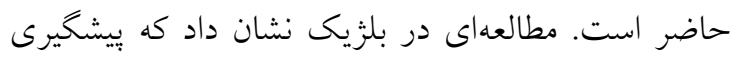

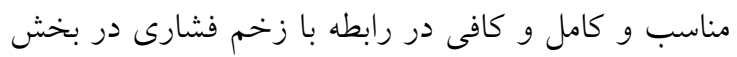

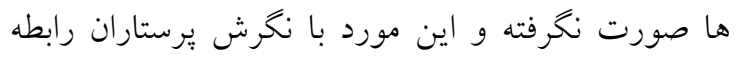

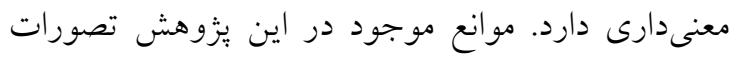

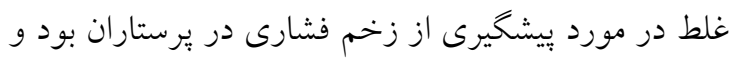

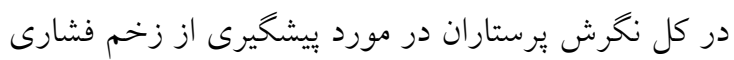

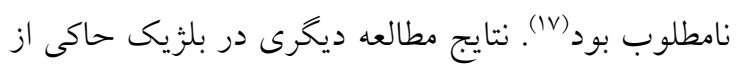

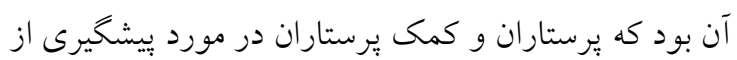

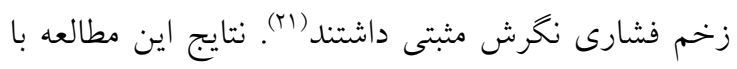

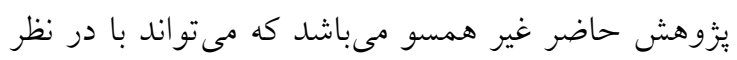

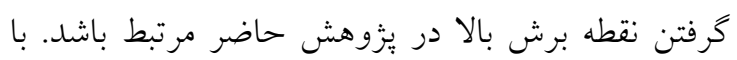

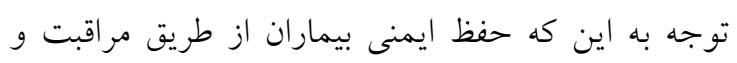

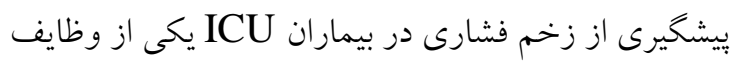

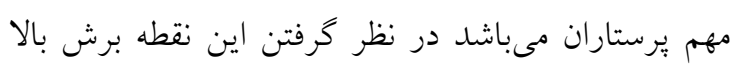
منطقى است. يافتها نشان داد نخرش زنان نسبت به مردان بخشتر بود. نكرش مثبتر يرستاران در مقايسه با مردان

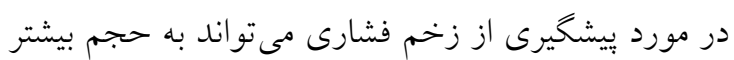
نمونه زنان مورد مطالعه در مقايسه با مردان مرتبط باشد.

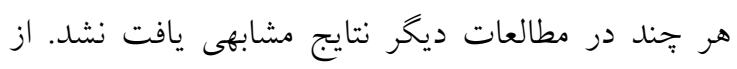

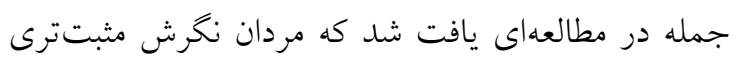

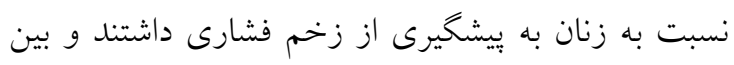

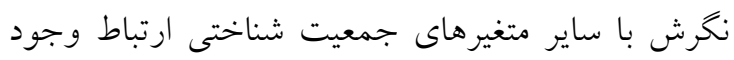

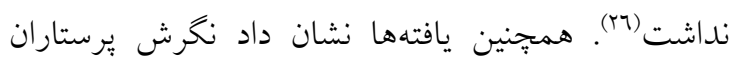

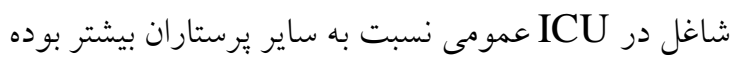

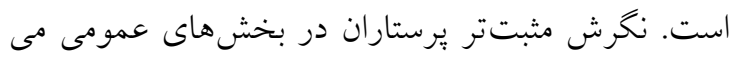

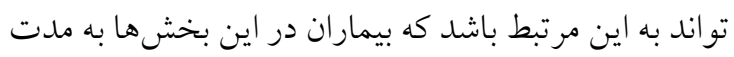

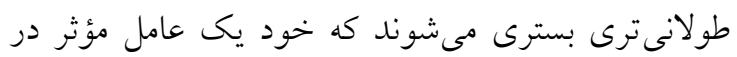

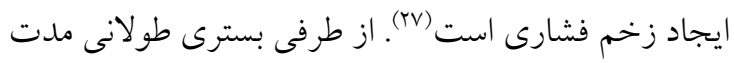

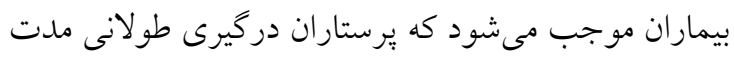




$$
\begin{aligned}
& \text { اساس نتايج آن مداخلات مناسب براى بهبود دانش، نخرش } \\
& \text { حضورى و غير حضورى براى تسهيل حضور يرستاران در } \\
& \text { و عملكرد آنها برنامه ريزى شود. }
\end{aligned}
$$

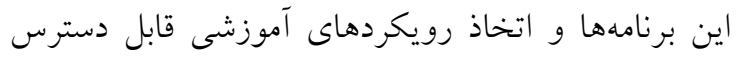

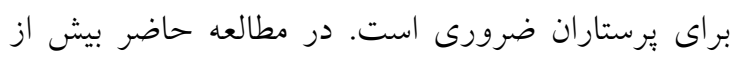

$$
\begin{aligned}
& \text { تعارض منافع:هيج گونه تعارض منافع از سوى نويسندگان }
\end{aligned}
$$

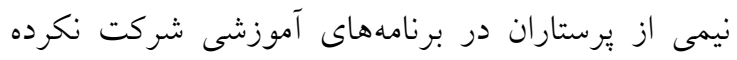

$$
\begin{aligned}
& \text { بيان نشده است. }
\end{aligned}
$$

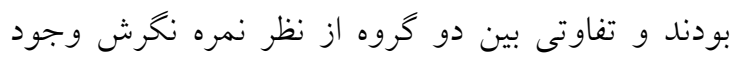

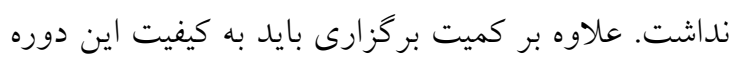

$$
\begin{aligned}
& \text { تقدير و تشكر }
\end{aligned}
$$

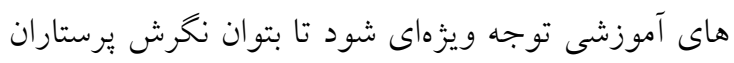

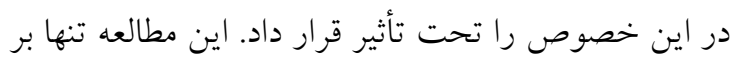

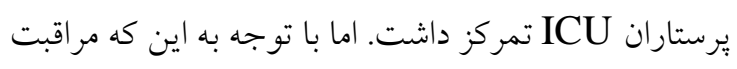

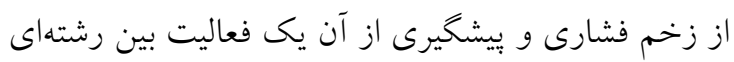

$$
\begin{aligned}
& \text { است ضرورى است دانش، نخرش و عملكرد ساير كاركنان } \\
& \text { سلامت علاوه بر يرستاران مورد بررسى قرار گرفته و بر }
\end{aligned}
$$

\section{References}

1. Demarre L, Van Lancker A, Van Hecke A, Verhaeghe S, Grypdonck M, Lemey J, et al. The cost of prevention and treatment of pressure ulcers: a systematic review. Int J Nurs Stud. 2015;52(11):1754-74.

2. Farzi S, Farzi S, Yousefii H, Moladoost A, Moieni M. Knowledge, Attitue and Practice of Nurses Concerning Pressure Ulcer Prevention and Its Relationship with Some Demographic Characteristics. Iranian Journal of Nursing Research (IJNR). 2016;11(4):66-70. [Persian]

3. Garrigues LJ, Cartwright JC, Bliss DZ. Attitudes of nursing students about pressure injury prevention. J Wound Ostomy Continence Nurs. 2017;44(2):123-8.

4. Beeckman D, Defloor T, Demarré L, Van Hecke A, Vanderwee K. Pressure ulcers: Development and psychometric evaluation of the Attitude towards Pressure ulcer Prevention instrument (APuP). Int J Nurs Stud. 2010;47(11):1432-41.

5. Galvão NS, Serique MAB, Santos VLCdG, Nogueira PC. Knowledge of the nursing team on pressure ulcer prevention. Rev Bras Enferm. 2017;70(2):294-300.

6. Clay AS, Chudgar SM, Turner KM, Vaughn J, Knudsen NW, Farnan JM, et al. How Prepared Are Medical and Nursing Students to Identify Common Hazards in the Intensive Care Unit? Ann Am Thorac Soc. 2017;14(4):543-9.

7. Estilo MEL, Angeles A, Perez T, Hernandez M, Valdez M. Pressure ulcers in the intensive care unit: new perspectives on an old problem. Crit Care Nurse. 2012;32(3):65-70.

8. Saifollahi Z, Bolourchifard F, Borhani F, Ilkhani M, Jumbarsang S. Correlation between Nurses' Knowledge and Quality of Nursing Care for Prevention of Pressure Ulcers in Intensive Care Units. Journal of hayat. 2016;22(1):90-101. [Persian]

9. Worsley PR, Clarkson P, Bader DL, Schoonhoven L. Identifying barriers and facilitators to participation in pressure ulcer prevention in allied healthcare professionals: a mixed methods evaluation. Physiotherapy. 2017;103(3):304-10.

10. Samuriwo R, Dowding D. Nurses' pressure ulcer related judgements and decisions in clinical practice: a systematic review. Int J Nurs Stud. 2014;51(12):1667-85.

11. Florin J, Bååth $\mathrm{C}$, Gunningberg L, Mårtensson G. Attitudes towards pressure ulcer prevention: a psychometric evaluation of the Swedish version of the APuP instrument. Int Wound $J$. 2016;13(5):655-62.

12. Simonetti V, Comparcini D, Flacco ME, Di Giovanni P, Cicolini G. Nursing students' knowledge and attitude on pressure ulcer prevention evidence-based guidelines: a multicenter cross-sectional study. Nurse Educ Today. 2015;35(4):573-9. 
13. Qaddumi J, Khawaldeh A. Pressure ulcer prevention knowledge among Jordanian nurses: a crosssectional study. BMC Nurs. 2014;13(1):6.

14. Dilie A, Mengistu D. Assessment of nurses' knowledge, attitude, and perceived barriers to expressed pressure ulcer prevention practice in Addis Ababa government hospitals, Addis Ababa, Ethiopia, 2015. Advances in Nursing. 2015;2015.

15. Tallier PC, Reineke PR, Asadoorian K, Choonoo JG, Campo M, Malmgreen-Wallen C. Perioperative registered nurses knowledge, attitudes, behaviors, and barriers regarding pressure ulcer prevention in perioperative patients. Appl Nurs Res. 2017;36:106-10.

16. El Enein NYA, Zaghloul AA. Nurses' knowledge of prevention and management of pressure ulcer at a Health Insurance Hospital in Alexandria. Int J Nurs Pract. 2011;17(3):262-8.

17. Beeckman D, Defloor T, Schoonhoven L, Vanderwee K. Knowledge and attitudes of nurses on pressure ulcer prevention: a cross-sectional multicenter study in Belgian hospitals. Worldviews Evid Based Nurs. 2011;8(3):166-76.

18. Källman U, Suserud BO. Knowledge, attitudes and practice among nursing staff concerning pressure ulcer prevention and treatment-a survey in a Swedish healthcare setting. Scand J Caring Sci. 2009;23(2):334-41. .

19. Strand T, Lindgren M. Knowledge, attitudes and barriers towards prevention of pressure ulcers in intensive care units: a descriptive cross-sectional study. Intensive Crit Care Nurs. 2010;26(6):33542.

20. Gunningberg L, Mårtensson G, Mamhidir AG, Florin J, Muntlin Athlin Å, Bååth C. Pressure ulcer knowledge of registered nurses, assistant nurses and student nurses: a descriptive, comparative multicentre study in Sweden. Int Wound J. 2015;12(4):462-8.

21. Demarré L, Vanderwee K, Defloor T, Verhaeghe S, Schoonhoven L, Beeckman D. Pressure ulcers: knowledge and attitude of nurses and nursing assistants in Belgian nursing homes. J Clin Nurs. 2012;21(9-10):1425-34.

22. Pieper B, Mott M. Nurses' knowledge of pressure ulcer prevention, staging, and description. Adv Wound Care. 1995;8(3):34-8.

23. Iranmanesh S, Tafti AA, Rafiei H, Dehghan M, Razban F. Orthopaedic nurses' knowledge about pressure ulcers in Iran: a cross-sectional study. J Wound Care. 2013;22(3):138-43.

24. Nuru N, Zewdu F, Amsalu S, Mehretie Y. Knowledge and practice of nurses towards prevention of pressure ulcer and associated factors in Gondar University Hospital, Northwest Ethiopia. BMC Nurs. 2015;14(1):34.

25. Etafa W, Argaw Z, Gemechu E, Melese B. Nurses' attitude and perceived barriers to pressure ulcer prevention. BMC Nurs. 2018;17(1):14.

26. Uba M, Alih F, Kever R, Lola N. Knowledge, attitude and practice of nurses toward pressure ulcer prevention in University of Maiduguri Teaching Hospital, Borno State, North-Eastern, Nigeria. International Journal of Nursing and Midwifery. 2015;7(4):54-60.

27. He M, Tang A, Ge X, Zheng J. Pressure ulcers in the intensive care unit: an analysis of skin barrier risk factors. Adv Skin Wound Care. 2016;29(11):493-8.

28. Tubaishat A, Aljezawi M, Al Qadire M. Nurses' attitudes and perceived barriers to pressure ulcer prevention in Jordan. $J$ Wound Care. 2013;22(9):490-7. 